\title{
GUSTAV MAYER
}

Even if Gustav Mayer had not been connected with the International Institute, we would still have commemorated him here as the most important historian of the German labour movement. Mayer died in London on February 21st, 1948. He left memoirs 1 ) in which the successes and disappointments of his life are pictured with creative power.

The scientific interest of Gustav Mayer was roused by Adolf Wagner and Gustav Schmoller, his university professors; Wagner was President of the Evangelisch-Sozialen Kongress and Schmoller was the founder of the Verein fuer Sozialpolitik. Both belonged to the 'catheder socialists'. Mayer, the young economist studied at first under Schmoller as he wanted to approach social-science from the historical rather than from the theoretical side. As a student, Mayer gave a lecture in Max Sering's seminary on the religious communist communities in the U.S.A. His thesis, Lassalle als Sozialökonom (1893) written on the instigation of G. Adler, dealt with the subject which later was to become his main field of interest. Long years of more practical work then followed. On Schmoller's instigation he took part in the research of the Verein fuer Sozialpolitik into the economic position of German handicrafts. For the next thirteen years he was corresponder of the Frankfurter Zeitung in Amsterdam, Brussels, Paris and Hamburg. As he wished to link up with democratic and socialist circles, he made himself known to many leading socialist politicians. It became a matter of course that he reported for the Frankfurter Zeitung on international congresses and major labour conflicts. The connections he laid in this way were most useful for his later work.

During his journalistic activities Gustav Mayer never lost

1) G. MAYER, Erinnerungen. Vom Journalisten zum Historiker der deutschen Arbeiterbewegung. Edited from the heritage and published by Mrs. Flora Mayer and Benedikt Kautsky. Europa Verlag, Zürich 1949. 
his interest in the history of social movements; in his Brussels period he gave many lectures before the Institut des Etudes Sociales; one of these was on the philosophical principles of German State Socialism in the nineteenth century. This field became his exclusive sphere of interest after he had been requested to write a contribution on the early German labour movement for a history of the Frankfurter Zeitung. It was to be published on the occasion of the 50th anniversary of the paper's foundation. During the following years Mayer worked on his first great Work: J. B. v. Schweitzer und die Sozialdemokratie (1909), which dealt with the history of the German labour movement from Lassalle's death until the fusion of both tendencies in 1875. Mayer's conception of Schweitzer's activity was close to that of Mehring and was an 'Ehrenrettung'. Bebel strongly opposed the views of both historians in the Neue Zeit. In the second volume of his memoirs Bebel recalled this period with the old, never-suppressed embitterment of the former political adversary of Schweitzer.

Gustav Mayer in his turn opposed this version in his criticism on Bebel's book. Mayer's work led him to the archives of Hamburg, Frankfurt and Berlin. He found the greatest newspaper collection of Germany in the Reichstag library. In the important archives of the Socialdemocratic Party he discovered a unique collection of party newspapers of the 60's. These and the Prussian Secret State archives became his main sources.

We can only mention here the most important discoveries and original works of the historian. In his study Die Trennung der proletarischen von der bürgerlichen Demokratie in Deutschland 1863-70, he dealt with the separation of independent workers' parties from the democratic wing of liberalism. The editing of Joh. Jacoby's posthumous papers led him to two of his most fundamental works. He succeeded in finding important material concerning Stirner, unknown to J. $\mathbf{H}$. Mackay, which shed light on the young-Hegelian circle of the 'Freien' (Die Anfänge des politisehen Radikalismus im vormärzlichen Preussen). He discovered the pseudonym of the young Frie- 
drich Engels and the hitherto anonymous early works (18381844), which threw new light on Engels's independent development to socialism; they were published as a supplement to the first volume of the Engels biography. Mayer was the first to have at his disposal the manuscript of the Deutsche Ideologie; he found letters from Heine to Marx and important autobiographical material by Marx. The culminating point of his work was the publication: The Engels biography (Vol. I, 1919, I/II, 1933), which became a standard work, and Nachgelassene Briefe und Schriften Ferdinand Lassalles (Vol. I, 1921, VI, 1925) the posthumous papers of Lassalle in six volumes, published, after much trouble, with the Hatzfeldt family. In 1928, this publication was followed by the correspondence between Lassalle and Bismarck. For the historical research this was terra incognita; until then to all intents and purposes conservative politicians only had been dealt with by official modern German historiography.

In 1916 Mayer wanted to become a lecturer in the Berlin University. Although he had the support of wellknown scholars such as Meinecke, Oncken, Delbriick, Marcks, and Herkner, his application was refused because of the objections of the 'alldeutsche' professors (under the leadership of D. Schäfer), on the ground of his 'insufficient historical knowledge'. This lasted until the advent of the Weimar Republic, when he obtained a lectureship for the history of democracy, socialism and the political parties; later he was given a professorship. He himself never belonged to a political party; he feared that otherwise his results of his investigations might be deemed party-political. Moreover, it would have been impossible for him to ask for a party's approval for his work. As it was, his work suffered by unfavourable political circumstances. The Engels biography, printed early in 1933, could only be saved by the sale of the whole edition, in great haste, to the publishing firm of Martinus Nijhoff in The Hague. Springer, the Berlin publishing company destroyed the remaining copies of the great Lasalle edition in 1937.

After the changes in 1933 Mayer had to leave Germany. He found a new home in England, and from 1936 onwards 
he placed his abilities at the disposal of the International Institute. He did research work for B. Nicolaevsky in the British Museum, on the great publication of the preliminaryhistory of the First International; most important material came to light. Further, he collected for the Institute much material on the Chartists for a publication on the English labour movement in the mid-Victorian era. His main sources were the Labour press and the trade union archives, and as the British labour movement was not yet centralized, the investigations led him to the archives and libraries of London, Manchester, Newcastle, Leeds, and other industrial towns. The result of this work was a richly documentated publication in two volumes: Die politische Geschichte der englischen Arbeiterbewegung von 1857-1872.

To the International Review for Social History Mayer contributed two papers: Zum Verständnis der politischen Aktion Lałalles (1938), in which he discussed Lassalle's standpoint on the problem of dictatorship, and Letters of Karl Marx to Karl Blind (1939) from the posthumous papers of the latter in the British Museum.

W. B. 